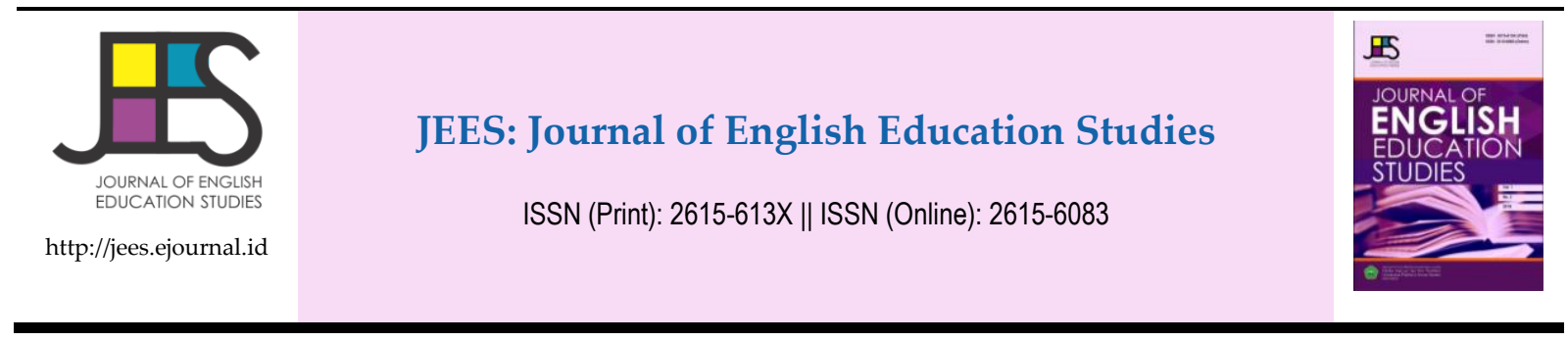

\title{
The Effect of PQRST and SGD Methods on Students' Reading Comprehension at Dehasen University
}

\author{
Mariska Febrianti ${ }^{1}$ \\ 1 Universitas Dehasen Bengkulu
}

\section{ARTICLE INFO}

Keywords:

PQRST Method

Small Group Discussion

Reading Comprehension

\begin{abstract}
This research aims to compare the effectiveness of two methods, PQRST (Preview, Question, Read, State and Test) and SGD (Small Group Discussion). It was carried out at the second semester students of Penjaskesrek Department, Dehasen University. The design was a quasi-experiment. The sample consisted of two classes; one was taught by the PQRST method and another by the SGD method. The instrument was a reading test, which was tried-out; the reliability was 0.917 (very high). The result was as follows: at the pretest, there was no significant difference between both group on all aspects and at the post test, there were no significant difference between both groups on general comprehension, reading to learn from the text, and reading to integrate information. However, SGD was found to be more effective on finding general information while PQRST was found to be more effective on reading to skim and finding simple information.
\end{abstract}

\section{INTRODUCTION}

Language is dynamic, it's developing and changing along the time. In line with the development, slang also develops. The slang exact origin is not known, possibly it is as old as language. Slang is considered as a unique language. It is unique because its existence is an interesting aspect in every language system, especially in English language system. There is no exact definition of slang available in the literature. The definition of slang is a wide concept.

Listening, speaking, reading and writing are four basic skills that have to be mastered by language learners because those skills are important to be developed by the students. Reading is one of the critical skills to improve students' general language skills. The students are expected to understand even well comprehend about the language. It will help students to build their other abilities because having good reading comprehension means that students know the vocabulary, grammar, and message conveyed. It is like what has been said by Hamra and Syatriana (2010) that the key to improve learning outcome in many field of research is reading. It is a necessary skill for foreign

\footnotetext{
${ }^{1}$ Corresponding author's address: Penjaskesrek Study Program, Teacher Training and Education Faculty of Universitas Dehasen Bengkulu, Indonesia e-mail: mariska.febby@unived.ac.id
} 
language students which should be mastered. The duties of students tend to comprehend any kinds of text. It is arranged to the purpose of reading to get information by constructing their creative thinking and combining prior knowledge, previous experience, situation and idea.

Indonesia has considered reading as one of the main language skills to focus on English subject since elementary school. Based on this fact, Eggen Paul (2005) assumed that students are expected to master reading in order to pass the National Examination. Nevertheless, in general, its ability tends to be unsatisfactory. The same issue also can be found in Indonesia according to Hamra and Syatriana (2010) many studies result indicated that the ability of Indonesian students to read English text was very low. On the other hand, Umiyati (2011) states that the government hopes that Indonesian students can master English language. Mastering English means that the students can develop their knowledge in every subject and communicate with other people from other countries.

Student in these cases not only in elementary school but also in Junior High School, Senior High School and College Students. And it happens to the researcher, in teaching and learning process in Health Physical and Recreation Education Department students. Health Physical and Recreation Education Department consists of three classes. While, the classes mostly consist of male, therefore lecturer often difficult to convey the information or materials because they feel difficult to focus on the materials. The students more like doing study outdoor or doing sports than in classroom to learn the theory. It is hard for lecturer to make students read English text. How can the information can be obtained by them if they still have low motivation.

Regarding the phenomena above, in order not to make the problems happen continually, the lecturer should find an appropriate method in teaching reading to help the students comprehend the text. There are many methods of language teaching that can be selected, for examples: PQRST (Preview, Question, Read, State, and Test) and small group discussion. Those methods had been applied in teaching and learning process of reading comprehension before by some other researchers.

Some previous studies are conducted such as by Sundari et al. (2010) who investigated experiment research. She combined PQRST (Preview, Question, Read, State, and Test) and CTL approach to find out students' improvement learning outcome on chemistry subject about periodic table. The result showed that PQRST method and CTL approach improve students' learning outcome on chemistry subject about periodic table. On the contrary, Sandiarsa et al. (2013) in his comparative research of PQRST (Preview, Question, Read, State, and Test) and SQ3R Strategies based on the text types upon the eighth grade students' reading competency at SMPN 4 Bali, showed that there was different effect between PQRST and SQ3R Strategies on students' reading competency and there is no interactional effect between both methods and text types (narrative and recount on students' reading competency.

Besides that, Septiari (2013) investigated PQRST (Preview, Question, Read, State, and Test) methods by using classroom action research methodology to students of SMPN 2 Banjarangkan Bali. She finds that PQRST could improve students reading comprehension. On the other hand, there are other researchers combine PQRST with approach such as: Febtiningsih et al. (2013) also investigated the same research about PQRST technique in students' reading comprehension at SMPN 2 West Sumatra. She concluded that students with low interest taught by PQRST technique had significantly higher reading comprehension on procedural text than those who were taught by QAR.

Moreover, Miqawati et al. (2014) studied PQRST on reading comprehension compare by using translation and reading aloud. From data statistic they found that PQRST strategy had impact on students' reading comprehension compared to the students taught by using translation and reading aloud.

From those researches above, they proved that PQRST technique is suitable method that can be applied in classroom. It is not only effective in experiment research but also in classroom action 
research and quasi experiment toward students' reading comprehension. Then, there is also another effective method that can be used to enhance students' reading comprehension namely Small Group Discussion.

Small group discussion is one method that needs students' participation and also good classroom management of the lecturer. There are some previous studies investigated small group discussion method, those are: Ria (2007) found that Small Group Discussion improved students in reading comprehension in EFL class (SMPN 1 Central Java). On the other hand, Umiyati (2011) in her research stated that small group discussion is more effective in teaching reading of descriptive text than whole class teaching.

Another previous studies by Ahmad (2013) found out the effectiveness of small group discussion method. This method effectively improve students reading skill and increase students' participation in class and built up their responsibility to finish the task.

According to those effective methods in teaching reading, the researcher found that the researcher gap from previous research, there are no comparison research related to PQRST and SGD in college students. Furthermore, the researcher considers to the current situation of teaching reading in low efficiency because most reading classes are lecturer centered and task based. Therefore, in a task based teaching class, the lecturer designs the tasks from different forms in order to evoke students' interest and organize lessons in a way that students can carry out the qualified reading tasks efficiency.

In conclusion, the researcher conducts PQRST (Preview, Question, Read, Summarize and Test) and SGD (Small Group Discussion) investigation, which was both considered as more effective method, on students' reading comprehension at Dehasen University.

\section{METHOD}

This research is conducted by using an experimental design. Whereas, according to Nunan (1992) experimental design is a step for investigating and testing hypothesis between variables that can be tested. On the other hand, Kothari (2004) remarks experiment is the process of examining the truth of statistical related to research problems and hypotheses. This research used a quasi-experimental design. In addition, Creswell (2012) says that quasi experiment is the development design from true experimental design which the variable cannot be randomly assigned. It because the interaction of variable and other factors.

There are three variables of this research, namely reading comprehension of students as dependent variable (Y); PQRST method (E1) and Small Group Discussion (E2). There were two independent variables in achieving objectives of the research. Pre-test and post-test applied in class to get the data by distributing instrument then analyzed by using t-test. This research has two experimental classes and lack of control group. The population is devided into two experimental groups. The first group was given the treatment of PQRST method and the second group was given the treatment of Small Group Discussion Method.

Table 1. Research Design of Research

\begin{tabular}{cccc}
\hline Group & Pre-Test & Treatment & Post-Test \\
\hline $\mathrm{E}_{1}$ & $\mathrm{~T}_{1}$ & $\mathrm{X}_{1}$ & $\mathrm{~T}_{1}$ \\
$\mathrm{E}_{2}$ & $\mathrm{~T}_{2}$ & $\mathrm{X}_{2}$ & $\mathrm{~T}_{2}$ \\
\hline \multicolumn{2}{c}{} & \multicolumn{3}{c}{ Arikunto $(2006)$}
\end{tabular}

Note :

E1 : Class which used PQRST method

$\mathrm{E}_{2}$ : Class which used SGD method 


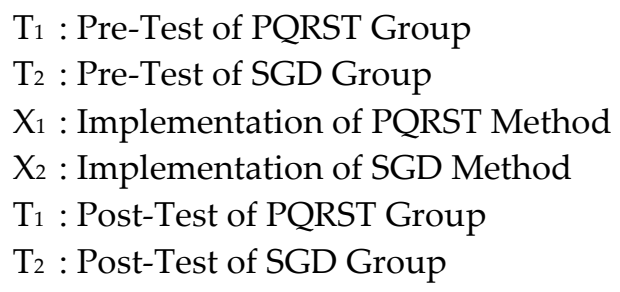

The experiment was carried out in 8 meetings, 6 times total treatments; pre-rest in the first meeting and also post-test at the end of meeting. Considering this research was aimed to investigate more effective method from PQRS and SGD on students' reading comprehension at Dehasen University, the hypothesis refers to:

1. General effect on students' general reading comprehension

$\mathrm{H}_{\mathrm{o}}$ : There is no difference between group means on students' whole reading comprehension.

$\mathrm{H}_{\mathrm{a}}$ : There is difference between group means on students' whole reading comprehension.

2. Effect on reading comprehension aspects, as follows:

a. Ha: There is difference between group means on students' reading comprehension in general information aspect.

Ho: There is no difference between group means on students' reading comprehension in general information aspect.

b. Ha: There is difference between group means on students' reading comprehension in skimming and searching for simple information aspect.

$\mathrm{H}_{\mathrm{o}}$ : There is no difference between group means on students' reading comprehension in skimming and searching for simple information aspect.

c. Ha: There is difference between group means on students' reading comprehension in learning from the text aspect.

$\mathrm{H}_{\mathrm{o}}$ : There is no difference between group means on students' reading comprehension in learning from the text aspect.

d. Ha: There is difference between group means on students' reading comprehension in integrating information aspect.

$\mathrm{H}_{\mathrm{o}}$ : There is no difference between group means on students' reading comprehension in integrating information aspect.

In analyzing the data, pre-test and post-test of the students score were collected and calculated to find out the average and the total score, standard deviation, and t-calculation. For pre-test data, the researcher found out the average score of students for each class. Parametric statistic used to find both mean comparative hypothesis of the data form of interval or ratio called t-test. Independent sample t-test was used in this study to find out the effectiveness of each method and to investigate the best methods.

\section{RESULT AND DISCUSSION}

\section{Result}

The researcher prepared try out instrument to students before giving treatment. Try out instrument must be done before the researcher gave treatments in class. There were 50 questions prepared about reading comprehension. Then, it was tested to students that not including into experimental class. There were only 25 questions which had validity value between 0.3 and 0.7 and also discrimination index score is to be equal 0.3 or more than 0.3 . Therefore, the number of valid questions became questions which were used as the instrument for pre-test and post-test. While, there were 25 questions for pre-test and post-test.

After examining the validity of research instrument by using KR-21, the reliability test result revealed that $R_{\text {total }}$ was 0.917 with the 25 items number of questions. It means that the instrument 
research was reliable with the reliability almost 1.00 . Thus, the instrument was able to be used as pre-test and post-test instruments.

\section{Analysis of the Data}

\section{Normality Test Result}

After trying out the instrument, the researcher did the research and gave the pre-test to the students. However, the normality of the students' pre-test result must be known to decide whether the sample was normal or not. Thus, the table below showed the normality test result on pre-test using Shapiro-Wilk formula.

Table 2. Normality on pre-test using Shapiro-Wilk

\begin{tabular}{|c|c|c|c|c|}
\hline \multirow{3}{*}{ Method } & \multirow[b]{2}{*}{ Type } & \multicolumn{3}{|c|}{ Shapiro-Wilk } \\
\hline & & Statistic & $\mathrm{df}$ & Sig. \\
\hline & 1 & .976 & 40 & .539 \\
\hline & 2 & .955 & 40 & .113 \\
\hline
\end{tabular}

a.Lilliefors Significance Correction

The table 4 showed that pre-test of PQRST and SGD method distributed normally. PQRST method has significant 0.539 , while SGD has significant 0.113 . Those methods distributed normally. The significant values of PQRST and SGD methods are $>0.05$.

Table 3. Normality on post-test using Shapiro-Wilk

\begin{tabular}{ccccc}
\hline & & \multicolumn{3}{c}{ Shapiro-Wilk } \\
\cline { 3 - 5 } Method & Type & Statistic & $\mathrm{df}$ & Sig. \\
\cline { 2 - 5 } & 1 & .968 & 40 & .321 \\
& 2 & .958 & 40 & .144 \\
\multicolumn{3}{c}{ a.Lilliefors Significance Correction } & \\
\hline
\end{tabular}

The table 5 showed that post-test of PQRST and SGD method distributed normally. PQRST method has significant 0.321, while SGD has significant 0.144 . Those methods distributed normally. The significant values of PQRST and SGD methods are $>0.05$.

\section{Homogeneity Test Result}

Based on the calculation of normality, the researcher got the result that all data in pre-test of both experimental group 1 and experimental group 2 have been distributed normally. The next steps of the calculation were finding the homogeneity of data using SPSS.

Table 4. Homogeneity of pre-test

\begin{tabular}{cccc}
\hline Levene Statistic & $\mathrm{df1}$ & $\mathrm{df2}$ & Sig. \\
.016 & 1 & 78 & .899 \\
\hline
\end{tabular}


Table 5. Homogeneity of post-test

\begin{tabular}{cccc} 
Levene Statistic & df1 & df2 & Sig. \\
.261 & 1 & 78 & .611 \\
\hline
\end{tabular}

The criteria of the test were in significance level 0.05 . From table above it can be seen that significant value of pre-test is $0.899>0.05$, meanwhile the significant value of post-test is $0.611>$ 0.05 . Therefore, both groups in pre-test and post-test were from homogeneous population.

\section{Independent Sample T-Test Result}

\section{Analysis to answer research question 1}

Independent sample t-test was used to answer research question no.1 (were PQRST and SGD methods equally effective on improving students' whole reading comprehension). Group means refer to the (test) mean of experimental group 1 which was taught by PQRST method, and (test) mean of experimental group 2, which was taught by SGD method.

Table 6. Analysis for Pre-Test

\begin{tabular}{cccccc}
\hline Class & Mean & $\mathbf{t}$ & df & Sig & Conclusion \\
\hline E1 & 47.50 & .176 & 78 & 0.861 & $\alpha=0.05$, Sig $=0.861>0.05 ;$ \\
E2 & 47.00 & .176 & 77.93 & 0.861 & $\begin{array}{c}\text { ME1 } \sim \mathrm{ME} 2(\operatorname{different} \text { between } \\
\text { ME1 and ME2 not sig) }\end{array}$ \\
\hline
\end{tabular}

From the table 6 the hypothesis related to the sub problem 1 was examined from independent sample t-test at pre-test. The analysis showed that significant value was $0.861>0.05$. It can be concluded that $\mathrm{H}_{\mathrm{o}}$ was accepted and $\mathrm{H}_{\mathrm{a}}$ was rejected. It means that there was no difference between students' reading comprehension test of PQRST and SGD methods before treatment. Further description of the data can be seen from the figures below.

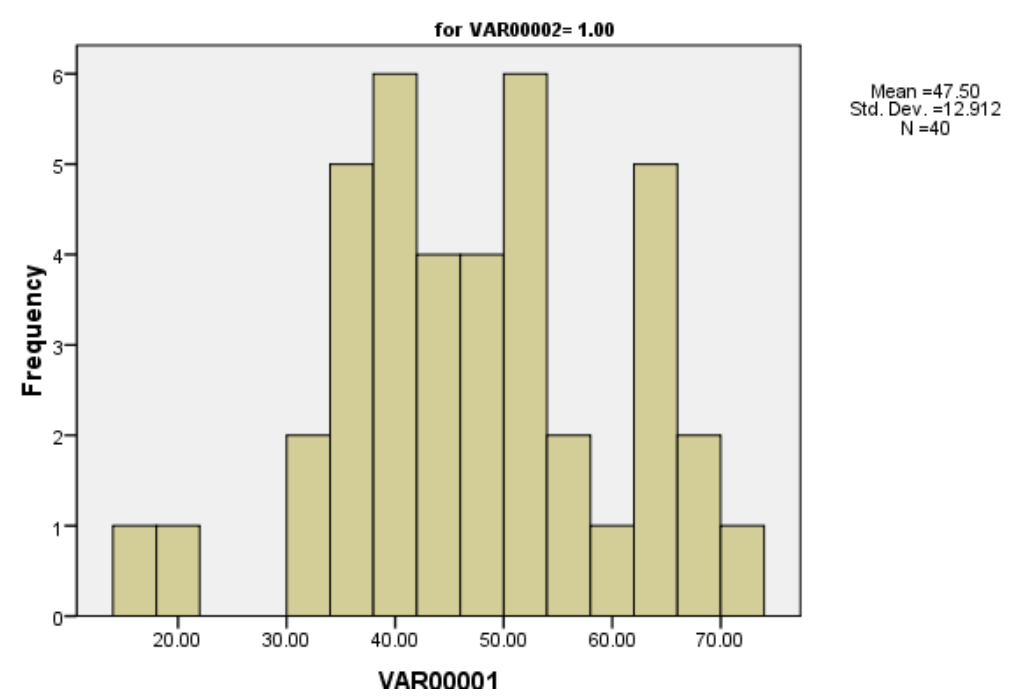

Figure 1. Students' score in pre-test of experimental group 1 


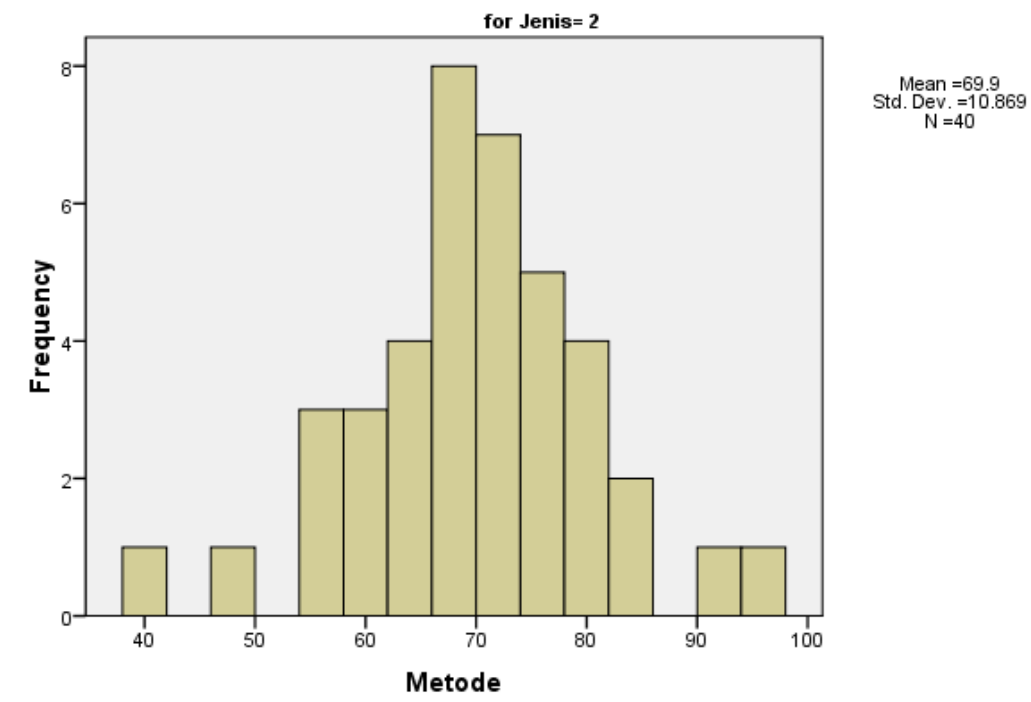

Figure 2.Students' score in pre-test of experimental group 2

Table 7. Analysis for Post Test

\begin{tabular}{|c|c|c|c|c|c|}
\hline Class & Mean & $t$ & df & Sig & Conclusion \\
\hline E1 & 67.90 & -.949 & 78 & 0.345 & $\alpha=0.05$, Sig $=0.345>0.05$ \\
\hline E2 & 69.90 & -.949 & 70.32 & 0.345 & $\begin{array}{l}\mathrm{ME1}_{\mathrm{E} \sim \mathrm{M}_{\mathrm{E}} \text { (different between }} \\
\mathrm{M}_{\mathrm{E} 1} \text { and } \mathrm{M}_{\mathrm{E} 2} \text { not sig) }\end{array}$ \\
\hline
\end{tabular}

From table 7 the hypothesis related to the sub problem 1 was examined from independent sample $\mathrm{t}$-test at post-test. The analysis showed that significant value was $0.345>0.05$. It can be concluded that $\mathrm{H}_{\mathrm{o}}$ was accepted and $\mathrm{H}_{\mathrm{a}}$ was rejected. It means that there was no difference between students' reading comprehension test of PQRST and SGD methods after treatment. Further description of the data can be seen from the figures below.

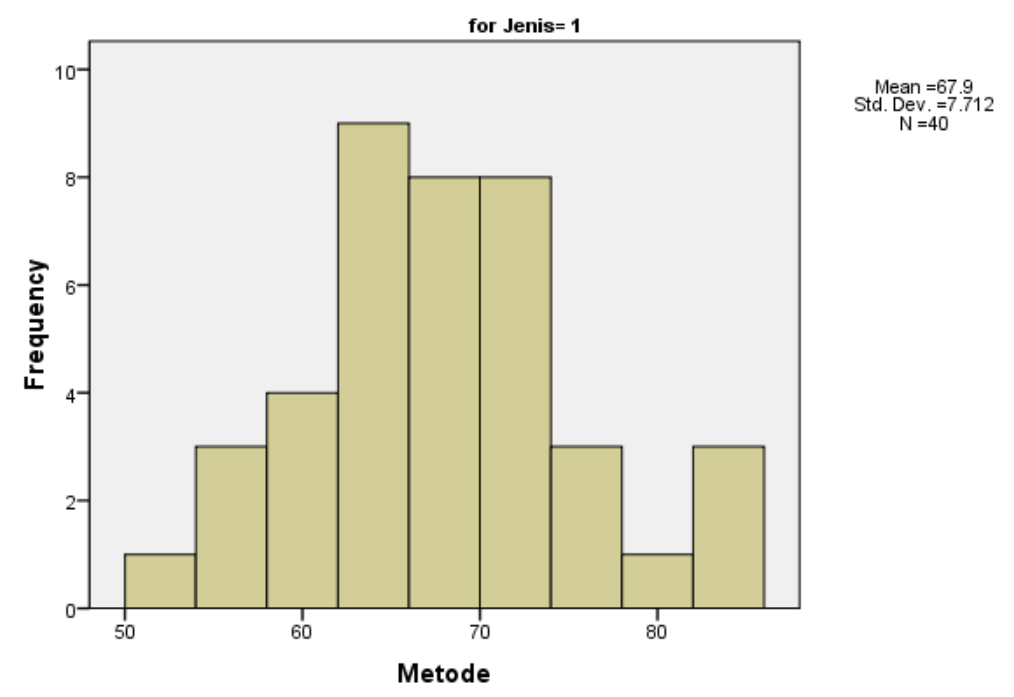

Figure 3. Students' score in post-test of experimental group 1 


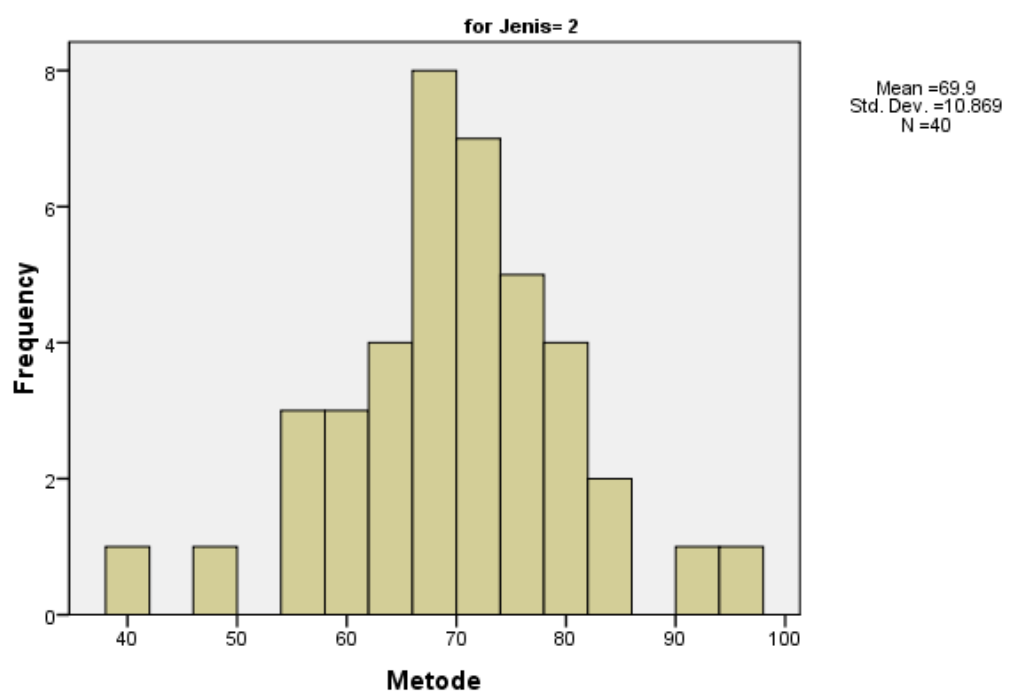

Figure 4. Students' score in post-test of experimental group 2

\section{Analysis to answer research question 2a}

Independent sample t-test was used to answer research question no.2a (were PQRST and SGD methods equally effective on improving students' reading comprehension in general information aspect).

Table 8. Analysis for Pre-Test

\begin{tabular}{cccccc}
\hline Class & Mean & t & df & Sig & Conclusion \\
\hline E1 & 55.90 & -1.553 & 78 & 0.124 & $\alpha=0.05$, Sig $=0.124>0.05 ;$ \\
E2 & 65.90 & -1.553 & 76.6 & 0.124 & $\begin{array}{c}\text { ME1 } \sim \text { ME2 (different between } \\
\text { ME1 and ME2 not sig) }\end{array}$ \\
\hline
\end{tabular}

From the table 8 , the hypothesis related to the sub problem 2a was examined from independent sample t-test at pre-test. The analysis showed that significant value was $0.124>0.05$. It can be concluded that $\mathrm{H}_{\mathrm{o}}$ was accepted and $\mathrm{H}_{\mathrm{a}}$ was rejected. It means that there was no difference between students' reading comprehension test of PQRST and SGD methods after treatment.

Table 9. Analysis for Post-Test

\begin{tabular}{cccccc}
\hline Class & Mean & $\mathbf{t}$ & $\mathbf{d f}$ & Sig & Conclusion \\
\hline E1 & 58.38 & -2.417 & 78 & 0.018 & $\alpha=0.05$, Sig $=0.018<0.05 ;$ \\
E2 & 74.28 & -2.417 & 68.46 & 0.018 & $\begin{array}{c}\text { ME1 } \sim \text { ME2 (different } \\
\text { between ME1 and ME2 sig) }\end{array}$ \\
\hline
\end{tabular}

From the table 9, the hypothesis related to the sub problem 2a was examined from independent sample t-test at post-test. The analysis showed that significant value was $0.018<0.05$. It can be concluded that $\mathrm{H}_{\mathrm{a}}$ was accepted and $\mathrm{H}_{\mathrm{o}}$ was rejected. It means that there was difference between students' reading comprehension test on general idea aspect of PQRST and SGD methods after treatment. In other words, SGD was more effective methods for students on general information aspect in reading comprehension. 


\section{Analysis to answer research question $\mathbf{2 b}$}

Independent sample t-test was used to answer research question number $2 \mathrm{~b}$ (were PQRST and SGD methods equally effective on improving students' reading comprehension in skimming and searching for simple information aspect)

Table 10. Analysis for Pre-test

\begin{tabular}{cccccc}
\hline Class & Mean & $\mathbf{t}$ & df & Sig & Conclusion \\
\hline E1 & 37.10 & 0.657 & 78 & 0.513 & $\alpha=0.05$, Sig $=0.513>0.05 ;$ \\
E2 & 35.12 & 0.657 & 77.96 & 0.513 & $\begin{array}{c}\text { MЕ1 MЕ2 (different between } \\
\text { MЕ1 and ME2 not sig) }\end{array}$ \\
\hline
\end{tabular}

According to table 10 , the hypothesis related to the sub problem $2 \mathrm{~b}$ was examined from independent sample t-test at pre-test. The analysis showed that significant value was $0.513>0.05$. It can be concluded that $\mathrm{H}_{\mathrm{o}}$ was accepted and $\mathrm{H}_{\mathrm{a}}$ was rejected. It means that there was no difference between students' reading comprehension test on skimming and searching simple information aspect of both methods before treatment.

Table 11. Analysis for Post Test

\begin{tabular}{cccccc}
\hline Class & Mean & $\mathbf{t}$ & df & Sig & Conclusion \\
\hline E1 & 63.62 & 13.15 & 78 & 0.00 & $\alpha=0.05$, Sig $=0.000<0.05 ;$ \\
E2 & 63.05 & 13.15 & 63.57 & 0.00 & $\begin{array}{c}\text { MЕ1 MЕ2 (different between } \\
\text { Mє1 and Mє2 sig) }\end{array}$ \\
\hline
\end{tabular}

From the table 11 , the hypothesis related to the sub problem $2 \mathrm{~b}$ was examined from independent sample t-test at post-test. The analysis showed that significant value was $0.00<0.05$. It can be concluded that $\mathrm{H}_{a}$ was accepted and $\mathrm{H}_{\mathrm{o}}$ was rejected. It means that there was significance difference between students' reading comprehension test in skimming and searching for simple information aspect of PQRST and SGD methods after treatment. Moreover, the researcher considering the mean of both methods, can conclude that PQRST group is more effective in skimming and searching for simple information aspect than SGD group.

\section{Analysis to answer research question 2c}

Independent sample t-test was used to answer research question no. 2c (were PQRST and SGD methods equally effective on improving students' reading comprehension in learning from the text aspect)

Table 12. Analysis for Pre-test

\begin{tabular}{cccccc}
\hline Class & Mean & $\mathbf{t}$ & df & Sig & Conclusion \\
\hline E1 & 57.58 & -0.216 & 78 & 0.883 & $\alpha=0.05$, Sig $=0.883>0.05 ;$ \\
E2 & 58.60 & -0.216 & 77.77 & 0.883 & $\begin{array}{c}\text { MЕ1 } \sim \text { ME2 (different between } \\
\text { ME1 and ME2 not sig) }\end{array}$ \\
\hline
\end{tabular}

From table 12, the hypothesis related to the sub problem $2 \mathrm{c}$ was examined from independent sample t-test at pre-test. The analysis showed that significant value was $0.883>0.05$. It can be concluded that $\mathrm{H}_{\mathrm{o}}$ was accepted and $\mathrm{H}_{\mathrm{a}}$ was rejected. It means that there was no difference between students' reading comprehension test on learning from the text aspect of both methods before treatment. 
Table 13. Analysis for Post-Test

\begin{tabular}{cccccc}
\hline Class & Mean & $\mathbf{t}$ & df & Sig & Conclusion \\
\hline E1 & 76.68 & 1.366 & 78 & 0.176 & $\alpha=0.05$, Sig=0.176 $>0.05 ;$ \\
E2 & 71.30 & 1.366 & 76.17 & 0.176 & $\begin{array}{c}\text { ME1 } \sim \text { ME2 (different between } \\
\text { ME1 and ME2 not sig) }\end{array}$ \\
\hline
\end{tabular}

Based on the table 13, the hypothesis related to the sub problem $2 \mathrm{c}$ was examined from independent sample $t$-test at post-test. The analysis showed that significant value was $0.176>0.05$. It can be concluded that $\mathrm{H}_{\mathrm{o}}$ was accepted and $\mathrm{H}_{\mathrm{a}}$ was rejected. It means that there was no difference between students' reading comprehension test on learning from the text aspect of PQRST and SGD methods after treatment.

\section{Analysis to answer research question 2d}

Independent sample t-test was used to answer research question number $2 \mathrm{~d}$ (were PQRST and SGD methods equally effective on improving students' reading comprehension in integrating information aspect)

Table 14. Analysis for Pre-Test

\begin{tabular}{cccccc}
\hline Class & Mean & $\mathbf{t}$ & df & Sig & Conclusion \\
\hline E1 & 45 & 0.000 & 78 & 1.00 & $\alpha=0.05$,Sig $=1.00>0.05 ;$ \\
E2 & 45 & 0.000 & 78 & 1.00 & $\begin{array}{c}\text { ME1 M M2(different between } \\
\text { ME1 and ME2 not sig) }\end{array}$ \\
\hline
\end{tabular}

From table 14 , the hypothesis related to the sub problem $2 \mathrm{~d}$ was examined from independent sample t-test at pre-test. The analysis showed that significant value $1.0>0.05$. It can be concluded that $\mathrm{H}_{\mathrm{o}}$ was accepted and $\mathrm{H}_{\mathrm{a}}$ was rejected. It means that there was no difference between students' reading comprehension test on integrating information aspect of both methods before treatment.

Table 15. Analysis for Post-Test

\begin{tabular}{cccccc}
\hline Class & Mean & $\mathbf{t}$ & df & Sig & Conclusion \\
\hline E1 & 63.75 & -1.815 & 78 & 0.073 & $\alpha=0.05$, \\
E2 & 75.00 & -1.815 & 78 & 0.073 & $\begin{array}{c}\text { Sig }=0.073>0.05 ; \\
\end{array}$ \\
& & & & $\begin{array}{c}\text { ME1 } \text { ME2 (different between } \\
\text { ME1 and ME2 not sig) }\end{array}$ \\
\hline
\end{tabular}

Based on the table 15, the hypothesis related to the sub problem $2 \mathrm{~d}$ was examined from independent sample t-test at post-test. The analysis showed that significant value was $0.073>0.05$. It can be concluded that $\mathrm{H}_{\mathrm{o}}$ was accepted and $\mathrm{H}_{\mathrm{a}}$ was rejected. It means that there was no difference between students' reading comprehension test on integrating information aspect of PQRST and SGD methods after treatment.

\section{Summary of the Analysis}

Based on the result of the research in general and aspects, the researcher summarized it into this table below: 
Table 16. Summary of result

\begin{tabular}{clcccc}
\hline No & \multicolumn{1}{c}{ Research Questions } & $\begin{array}{c}\text { Pre } \\
\text { test }\end{array}$ & Note & $\begin{array}{c}\text { Post } \\
\text { test }\end{array}$ & Note \\
\hline 1 & Reading comprehension & 0.861 & Not Sig & 0.345 & Not Sig \\
2 & General information aspect & 0.124 & Not Sig & 0.018 & Sig \\
3 & $\begin{array}{l}\text { Skimming and searching for } \\
\text { simple information aspect }\end{array}$ & 0.513 & Not Sig & 0.000 & Sig \\
4 & Learning from the text aspect & 0.883 & Not Sig & 0.176 & Not Sig \\
5 & $\begin{array}{l}\text { Integrating information } \\
\text { aspect }\end{array}$ & 1.000 & Not Sig & 0.073 & Not Sig \\
\hline
\end{tabular}

Based on the table 16. the result not significant means that PQRST and SGD methos were equally effective, while significant means that there was one method more effective that other method.

\section{Discussion}

As previously mentioned, the main purpose of this research was to know which ones of PQRST and Small Group Discussion was more effective methods on students' reading comprehension at Penjaskesrek Department, Dehasen University. From analysis of pre-test and post-test that the researcher got, there was no difference on students' general reading comprehension between both methods before and after treatments. It also happened in several aspects such as: the aspect of learning from the text and integrating information. Meanwhile, in general information aspect SGD was more effective method for students' reading comprehension. On the other hand, in skimming and searching simple information aspect, PQRST was more effective to students' reading comprehension.

SGD method can be called as team work, because the member in group shared their ideas between their friends and discussed the solution of the task that lecturer gave. It also similar to Barker (1987) who states that the Small Group Discussion is technique how to learn and found out and work together with member in the group that know well enough to trust each other. According to that explanation, it can be linked to the finding on first aspect, that was general idea. Students in experimental class 2 have significant difference in general information aspect because the activities applied in class made students could share the ideas and discuss to find the answer of the question with their friends. Therefore, it could help students easier understand the general information of the reading material.

It also has the same point to Sagala (2008) who elaborates that discussion is more effective way that enable students to give their opinions to other students easily and free to talk and discuss to answer the question. The activity in discussion can be useful if the members have the same motivation to learn but it can't be guaranteed because there were many characters of students in class. That is the lack of this method, but it can be overcome by the lecturer when dividing individual into group. Lecturer must know and observe the characteristics and skills of students.

Furthermore, PQRST was also proved as more effective method similar to Small Group Discussion but in different aspect. There was significant difference on skimming and searching specific information of students' reading comprehension because its method also has strength. In the regulation of that method applied in the class made the students easier to read the material from several steps with that method. The lecturer must focus and make sure the students know what they will do related to the method. In other word, the lecturer must explain the concepts and each steps clearly in front of the class before students did the activity. For example in question step of PQRST 
method, students made some questions before they read the text. The activity can improve their knowledge because they have had the purposed of reading the text.

Meanwhile, the result also confirmed to the theory from Champion (2006) which states that PQRST enhances the process of brain to extend the information, especially in written material. The goal of PQRST method is to help the students advance their reading comprehension.

The result of this study was also similar to the result of some previous studies. Firstly, Febtiningsih et al. (2013) proved that PQRST is effective method to develop students' reading competency. This study was in line to the present study that PQRST method was effective method in reading comprehension in general, but it also effective on skimming and searching for simple information aspect. It can be seen from students' score in experimental group 1 was more than experimental group 2.

Secondly, Sandiarsa et al. (2013) found that there was different effect between PQRST and SQ3R strategies on students' reading competency and there was no interactional effect between both methods and text types. It almost similar to the result of this study although this study has different compared method, that was Small Group Discussion. However, PQRST was effective method on skimming and searching for simple information aspect towards students reading comprehension.

Thus, PQRST method has been proven to help students as individuals remember the information easier. Although, the lecturer needs to concern and describe clearly to the students about the concept. Moreover, PQRST method was useful to enhance students' reading comprehension but SGD also effective in general information aspect to students. It also can make students more active in the class by the interaction each other in group that cannot happen in PQRST method. PQRST might be more suitable to students that usually work individually. They must push their own motivation to follow several steps on that method.

In conclusion, PQRST and SGD were effective methods in students' reading comprehension especially for students in Penjaskesrek Department. While, SGD was more effective on general information aspect and PQRST was more effective on skimming and searching for simple information aspect. Although, the lecturer used Indonesian and English to applied both methods. That is a way for another researcher learn from the text and integrate information aspect which can be used for further study to the other object. This research was done to students' of Penjaskesrek Department, who generally had low average of English ability. Thus, if it is done on students with high average of English ability, the result may be different.

\section{CONCLUSION}

From the result of the research, it can be concluded that PQRST (Preview, Question, Read, State and Test) and SGD (Small Group Discussion) methods were general equally effective on students' reading comprehension. However, there are some differences in effectiveness, as follows: (a) SGD method was more effective than PQRST method on the aspect of general information. (b) PQRST method was more effective than SGD method on the aspect of skimming and searching for simple information. Overall, PQRST (Preview, Question, Read, State and Test) and SGD (Small Group Discussion) methods were equally effective in general and in two aspects, however there were two aspects in which their effectiveness were not equal.

Based on the result of research, there are some suggestions that can be divided by the reseacher as follows :

First, for the lecturer, the researcher suggests to use PQRST as an alternative in teaching reading on reading to skim or search simple information. Besides that, SGD also can be an alternative way in teaching reading method on general information. Thus, the lecturer should be aware of the conditions of the students nowadays, in order to select knowledge about various methods in teaching and learning and be more creative in motivating their students. 
Second, other studies recommended to compare PQRST and SGD to study more deeply on reading comprehension, especially on reading to learn from the text and reading to integrate information aspect.

\section{REFERENCES}

Ahmad, C. (2013). The Effectiveness of Small Group Discussion Method in Teaching Reading. Bandung: Universitas Pendidikan Indonesia.

Arikunto, S. (2006). Prosedur penelitian suatu pendekatan praktek. Jakarta, Indonesia: Rineka Cipta.

Barker, L. (1987). Communication. Englewood Cliffts. New Jersey: Prentice Hall. Inc.

Champion, A. J. (2006). Neuropsychological rehabilitation: A resource for group-based education and intervention. England: John Wiley \& sons Ltd.

Cresswell, J. W. (2012). Educational research : Planning, conducting, and evaluating quantitative and qualitative research. Boston: Pearson Education.

Febtiningsih, P., Zaim \& Jufrizal. (2013). The Effect of PQRST and QAR techniques on students' with low interest on their reading comprehension procedure texts: Study at grade vii of SMPN 2 padang. West Sumatra, Indonesia: Journal English Language Teaching (ELT) Vol. 1 No. 1.

Hamra \& Syatriana, (2010). Developing a model of teaching reading comprehension for efl students. Teflin Journal Vol. 21 No. 1 p. 28

Heaton, J. B. (1998). Writing english language test. England: Longman Group UK Limited.

Kothari C. R. (2004). Research methodology: Method and techniques. New Delhi, India: New Age International Publisher.

Miqawati, A., \& Sulistyo, H.(2014). The PQRST strategy, reading comprehension and learning styles. Indonesian Journal of Applied Linguistic.Vol. 4 No.1.

Nunan, D. (1992). Research method in language learning. New York: Cambridge University Press.

Paul, E. (2005). Methods for teaching promoting students learning in K-12 classroom. Boston, San Fransisco: Allin Bacon.

Ria, A. (2007). The Teaching of reading comprehension by using small group discussion method at the first year students of smpn 1 wanadadi. Semarang, Indonesia : Universitas Negeri Semarang.

Sagala, S. (2008). Konsep dan makna pembelajaran. Bandung, Indonesia : Alfabeta.

Sandiarsa, S., Tantra, D., \& Ratminingsih, N. M. (2013). Comparative study of PQRST and SQ3R strategies based on the text types upon the eighth grade students' reading competency at smpn 4 bali. Bali, Indonesia: e-jurnal Program Pasca sarjana Universitas Pendidikan Ganesha Vol. 1.

Septiari. (2013). Improving reading comprehension through PQRST students reading comprehension of eight grade students of SMPN 2 banjarangkan. Bali, Indonesia: Mahsaraswati Denpasar University.

Sundari, M., Wijaya, N. \& Isni, L. (2010).The Use of PQRST method with CTL approach toward students' learning outcome on chemistry subject. Semarang, Indonesia: Jurnal Inovasi Pendidikan Kimia Vol. 4 No. 1.

Umiyati. (2011). The Effectiveness of small group interaction in teaching reading comprehension (experimental study at seventh grade of SMP sunan bonang, tangerang). Jakarta, Indonesia: Syarif Hidayatullah State Islamic University. 